\title{
APLIKASI MESIN SPINNER BERKECEPATAN RENDAH UNTUK MENURUNKAN KADAR AIR DAN MINYAK KERIPIK IKAN UKURAN BESAR DI UKM BERKAH
}

\section{APLICATION LOW SPEED SPINNER MACHINE TO REDUCE MOISTURE AND LIPID CONTENT IN BIG SIZE FISH CHIPS IN UKM BERKAH}

\author{
Laras Rianingsih" ${ }^{1)}$ Ulfah Amalia ${ }^{1)}$, Ima Wijayanti ${ }^{1)}$ dan Slamet Suharto ${ }^{1)}$ \\ ${ }^{1)}$ Program Studi Teknologi Hasil Perikanan Fakultas Perikanan dan Ilmu Kelautan Universitas Diponegoro \\ Jl.Prof. H. Soedarto, SH Tembalang Telp/Fax. (024) 7474698 Semarang-50275 \\ Email : laras_rianingsih@yahoo.com
}

Diserahkan [29 Juli 2018]; Diterima [22 Agustus 2018]; Dipublikasi [31 Agustus 2018]

\section{ABSTRACT}

Rawa pening is a water area located in the Banyubiru area of Semarang Regency. Aside from being used as a place for fish farming, the area around Rawa Pening is used as a tourist spot for example "Bukit Cinta". Around the location it will be easy to find entrepreneurs who provide souvenirs typical of these tourist locations. The typical Bukit Cinta souvenirs is a variety of chips, including fish chips. There are 2 fish chips in Bukit Cinta, small size chips and large size chips. The problem was the shelf life of large size chips is short because they cannot be spinered so that the oil content is still high and than pronoun to oxidation. Low speed spiner tools can be a solution to overcome existing problems. The results of the spinner machine application are obtained lower moisture content and lipid content than products without being spinnered. Moisture content after the spinning process using spiner machine, the wader chips was $3.25 \%$ and tilapia chips were $3.97 \%$. While the wader chips lipid content was $31.16 \%($ bk) and tilapia chips $3.97 \%(\mathrm{db})$.

Keywords: Fish chips, Spinner machine, Moisture content, Lipid content

\section{ABSTRAK}

Rawa pening merupakan daerah perairan yang terletak di daerah Banyubiru Kabupaten Semarang. Selain digunakan sebagai tempat budidaya ikan, daerah sekitar Rawa Pening banyak dijadikan tempat wisata salah satunya adalah Bukit Cinta. Sebagaimana lokasi wisata pada umumnya, disekitar lokasi akan mudah ditemukan para pengusaha yang menyediakan buah tangan khas lokasi wisata tersebut. Buah tangan khas Bukit Cinta adalah berbagai keripik, termasuk keripik ikan. Keripik ikan yang ada di Bukit Cinta ada 2 ukuran yaitu keripik ukuran kecil dan keripik ukuran besar. Permasalahan yang ada adalah keripik ukuran besar tidak tahan lama karena tidak bisa di spinner sehingga kadar minyaknya masih tinggi. Alat spiner dengan kecepatan rendah dapat menjadi solusi untuk mengatasi permasalahan yang ada. Hasil aplikasi mesin spinner maka diperoleh kadar kadar air dan kadar minyak yang lebih rendah daripada produk yang tanpa di spinner. Kadar air setelah proses penirisan menggunakan mesin spinner keripik wader adalah 3,25\% dan keripik nila adalah 3,97\%. Sedangkan kadar minyak keripik wader adalah 31,16\% (bk) dan keripik nila 3,97\% (bk).

Kata Kunci : Keripik ikan, Mesin spiner, Kadar air, Kadar minyak

\section{PENDAHULUAN}

Pemerintah melalui Kementerian Kelautan dan Perikanan telah mencanangkan pada tahun 2014 Indonesia menjadi produsen ikan budidaya terbesar di dunia. Dari sisi potensi sumberdaya lahan yang tersedia, Provinsi Jawa Tengah memiliki potensi lahan budidaya secara keseluruhan mencapai luas 562,247 ha, dengan garis pantai yang mencapai $828,8 \mathrm{~km}$ dan ditunjang dengan kondisi iklim tropisnya sangat memungkinan untuk pelaksanaan aktivitas usaha pembudidayaan ikan sepanjang tahun. Sementara itu, potensi lahan budidaya tambak (air payau) diperkirakan mencapai 40.000 ha. Sedangkan potensi lahan untuk budidaya kolam yang diperkirakan seluas 50.000 ha. Budidaya di perairan umum diperkirakan seluas 9.000 ha, sementara lahan budidaya sawah berpengairan teknis yang mencapai 190.000 ha. Kesemuanya itu menunjukkan bahwa potensi usaha perikanan budidaya di Provinsi Jawa Tengah masih 
sangat besar dan belum sepenuhnya dimanfaatkan, sehingga masih terbuka peluang untuk pengembangan pemanfaatannya secara lestari dan berkelanjutan.

Rawa pening merupakan daerah perairan yang terletak di daerah Banyubiru Kabupaten Semarang. Perairan ini banyak digunakan sebagai tempat budidaya terutama adalah ikan nila dan mujaer. Selain digunakan sebagai tempat budidaya ikan, daerah sekitar Rawa Pening banyak dijadikan tempat wisata misalnya adalah Bukit Cinta Rawa Pening dan Kampung Rawa. Bukit Cinta adalah lokasi wisata yang mengedepankan pemandangan perairan rawa. Sebagaimana lokasi wisata pada umumnya, di sekitar lokasi akan mudah ditemukan para pengusaha yang menyediakan buah tangan khas lokasi wisata tersebut. Buah tangan khas Bukit Cinta adalah berbagai keripik, termasuk keripik ikan. Keripik ikan yang ada di Bukit Cinta ada 2 ukuran yaitu kekripik ukuran kecil dan keripik ukuran besar. Keripik ukuran kecil adalah keripik cethul, keripik udang, keripik teri tambak dan teri rawa. Sedangkan keripik ukuran besar adalah keripik wader dan keripik nila. Keripik berukuran kecil sebelum dikemas akan di spinner untuk mengurangi kadar minyaknya. Keripik yang berukuran besar tidak bisa di spinner karena akan hancur selama proses penirisan menggunakan mesin spinner.

Keripik ikan yang dihasilkan ada 2 ukuran. Produk dengan ukuran kecil (keripik udang, cethul, teri tambak dan teri rawa) mampu bertahan selama 3 bulan menurut pengolah. Sedangkan keripik yang berukuran besar (keripik belut, kulit ikan dan ikan nila) hanya bisa bertahan selama 1 bulan. Perbedaan daya simpan ini disebabkan oleh karena keripik ikan dengan ukuran besar tidak di tiriskan minyaknya dengan spinner peniris minyak sedangkan produk berukuran kecil ditiriskan dengan spinner sehingga kadar minyak akan rendah dan lebih tahan terhadap oksidasi. Produk dengan ukuran besar tidak bisa ditiriskan menggunakan spinner karena design spinner biasa yang dijual dipasaran mempunyai kecepatan putar yang tinggi sehingga produk besar akan menjadi hancur saat ditiriskan minyaknya menggunakan spinner tersebut. Menurut Felayati et al. (2016), terdapatnya air dalam minyak akan merusak minyak. Kerusakan terjadi karena air dapat menghidrolisis minyak dan juga minyak menjadi mudah teroksidasi. Hasil oksidasi primer adalah hidroperoksida dan hasil oksidasi sekunder adalah aldehid, keton yang mampu menyebabkan bau tengik pada produk.

Jalan keluar dari masalah ini adalah dialikasikannya sebuat spinner modifikasi khusus untuk produk dengan ukuran yang relatif lebih besar. Spinner dengan kecepatan rendah diharapkan tidak memberi gaya tekan yang terlalu tinggi pada produk sehingga produk tidak pecah atau hancur. Untuk mengoptimalisasi pengurangan minyak dapat dilakukan dengan penambahan waktu spinning setiap batch proses. Dengan alat modifikasi ini diharapkan produk dapat berkurang kadar minyaknya sehingga menjadi lebih awet akan tetapi bentuknya tidak rusak atau hancur selama proses spinning. Gambaran teknologi spinner dari bahan yang aman untuk pengolahan makanan dan diatur pada putaran sekitar $800 \mathrm{rpm}$ selama 3 menit (Suparlan, 2012).

\section{METODE PENELITIAN}

\section{Bahan}

Bahan yang digunakan adalah keripik ikan, petroleum eter, $\mathrm{H}_{2} \mathrm{SO}_{4}, \mathrm{NaOH}, \mathrm{H}_{3} \mathrm{BO}_{3}$, $\mathrm{CuSO}_{4}, \mathrm{HCl}$, Akuades dan BCG-MR.

\section{Alat}

Alat yang digunakan Spiner, soxhlet apparatus, Kjeldahl apparatus, tanur, moisture analyzer.

\section{Tahapan Penelitian}

Keripik ikan hasil olahan UKM Berkah dalam kondisi baru saja digoreng dibagi menjadi 2 bagian. 1 bagian langsung dikemas menggunakan plastik dan 1 bagian ditiriskan minyaknya menggunakan spinner modifikasi selanjutkan dikemas menggunakan plastik dan 
dibawa ke laboratorium Fakultas Perikanan dan Ilmu Perikanan, Universitas Diponegoro untuk dianalisa proksimat meliputi kadar air (BSN, 2008), kadar protein (BSN, 2006), kadar lemak (BSN, 2006) dan kadar abu (BSN, 2010).

\section{HASIL DAN PEMBAHASAN}

Spiner modifikasi yang pada UKM Berkah ini dibuat dari stainless steel. Pemberian spinner modifikasi ini bertujuan untuk digunakan pada produk keripik ikan berukuran besar. Keripik ikan berukuran besar akan hancur bila ditiriskan minyaknya menggunakan spinner biasa. Dengan spinner modifikasi berkecepatan rendah ini keripik ikan besar tidak akan hancur. Kecepatan putaran yang rendah akan melindungi produk akan tetapi memerlukan waktu putar yang lebih panjang daripada spinner biasa yaitu kurang lebih menjadi 2 kali lipat waktu pengeringan dengan spinner biasa. Ukuran atau volume spinner modifikasi juga dibuat menjadi lebih besar supaya kapasitasnya lebih besar. Dengan penirisan minyak ini maka kadar lemak atau minyak dalam produk akan menurun sehingga diharapkan daya simpan produk menjadi lebih panjang karena lebih terlindung dari proses oksidasi.

Tabel 1 menunjukkan kadar proksimat keripik ikan berukuran besar yaitu keripik ikan wader dan keripik ikan nila. Berdasarkan Tabel 1, dapat kita ketahui bahwa dengan penggunaan spinner maka kadar air dan kadar lemak akan mengalami penurunan, sedangkan kadar protein akan mengalami kenaikan.
Kadar air pada kedua sampel mengalami penurunan. Keripik ikan wader awal memiliki kadar air 3,4\% dan setelah ditiriskan menggunakan mesin peniris spinner kadar air menjadi turun menjadi 3,25\%. Begitu pula pada keripik ikan nila. Kadar air awal keripik ikan nila adalah 4,19\% dan turun menjadi 3,97\% setelah ditiriskan dengan mesin spinner.

Kadar lemak atau minyak juga mengalami penurunan. Keripik wader memiliki kadar minyak awal 32,84\% dan turun menjadi $31,16 \%$ setelah di spinner. Keripik nila memiliki kadar lemak awal 35,49\% dan turun menjadi 33,68\%. Ukuran keripik ikan nila lebih besar daripada keripik wader sehingga kadar air dan kadar minyaknya lebih tinggi keripik nila.

Mesin peniris spinner bekerja dengan prinsip sampel dimasukkan dalam mesin akan diputar oleh mesin yang digerakkan oleh motor listrik. Saat terjadi pemutaran akan terjadi sentrifugal sehingga sampel akan bergeser kearah pinggir keranjang dalam mesin. Bahan yang lebih kecil dari ukuran lubang keranjang termasuk minyak akan terlempar keluar sehingga kandungan minyak dalam sampel akan turun dan akhirnya produk menjadi semakin kering dan renyah (Nugraha et al., 2014)

Kadar abu dan kadar protein cenderung tidak banyak berubah. Hal ini karena selama proses penirisan, komponen protein dan abu tidak banyak dipengaruhi oleh gaya sentrifugal dalam mesin spinner. Protein adalah makromolekul dan berbentuk padat sehingga sulit untuk keluar atau hilang selama pemutaran dalam mesin. Abu adalah mineral yang keberadaannya terikat dalam sampel. Bahan ini juga sulit untuk lepas bila hanya diberi perlakuan pemutaran atau gaya sentrifugal dalam mesin peniris.

Tabel 1. Nilai Proksimat keripik ikan sebelum dan sesudah ditiriskan dengan alat spinner modifikasi (\%)

\begin{tabular}{cccccc}
\hline No. & Sampel & Kadar air (bk) & Kadar abu (bk) & Kadar protein (bk) & Lipid (bk) \\
\hline 1. & Wader awal & $3,4 \pm 1,32$ & $11,68 \pm 0,20$ & $25,31 \pm 0,29$ & $32,84 \pm 0,15$ \\
2. & Wader spinner & $3,25 \pm 0,74$ & $11,65 \pm 0,13$ & $25,60 \pm 0,16$ & $31,16 \pm 0,17$ \\
3. & Nila Awal & $4,19 \pm 0,74$ & $14,93 \pm 0,02$ & $23,09 \pm 0,17$ & $35,49 \pm 0,16$ \\
4. & Nila spinner & $3,97 \pm 0,83$ & $14,66 \pm 0,06$ & $23,94 \pm 0,15$ & $33,68 \pm 0,29$ \\
\hline
\end{tabular}

Keterangan :

Data \pm standar deviasi 


\section{KESIMPULAN}

Kadar air dan kadar minyak keripik ikan wader akan mengalami penurunan sebesar $5,25 \%$ dan $5,1 \%$ apabila ditiriskan menggunakan alat spiner peniris. Kadar air dan kadar minyak keripik ikan nila akan mengalami penurunan sebesar $4,4 \%$ dan $5,11 \%$ apabila ditiriskan menggunakan alat spiner peniris.

\section{DAFTAR PUSTAKA}

Badan Standarisasi Nasional. (2006). Standar Nasional Indonesia (SNI) 012354.2-2006 Cara Uji Kimia- Bagian 2: Penentuan kadar air pada produk perikanan. Jakarta.

Badan Standarisasi Nasional. (2006). Standar Nasional Indonesia (SNI) 012354.3-2006 Cara Uji Kimia- Bagian 3: Penentuan Kadar Lemak Total pada Produk Perikanan. Jakarta.

Badan Standarisasi Nasional. (2006). Standar Nasional Indonesia (SNI) 012354.4-2006 Cara Uji Kimia- Bagian 4: Penentuan Kadar Protein dengan Metode Total Nitrogen pada Produk Perikanan. Jakarta.

Felayati, H. F., Susilo, B. dan Sugiarto, Y. (2016). Uji Performansi Mesin "Spiner Pulling Oil" Sebagai Pengentas Minyak Otomatis dalam Peningkatan Produktifitas Abon Ikan Patin (Pangasius pangasius). Jurnal Keteknikan Pertanian Tropis dan Biosistem, 4(1) : 41-47.

Nugraha M,A., Helmi F, F., Alvian B. I., Bambang S., Bambang D. A., Musthofa L. dan Yusron S. (2014). Rancang Bangun Alat "Spinner Pulling Oil" Sebagai Pengentas Minyak Otomatis dalam Peningkatan Mutu Abbon Ikan Patin (Pangasius pangasius) Pada Koperasi Wanita Srikandi. Jurnal Teknologi Pertanian, 15(2) : 103-110.

Suparlan. (2012). Pengembangan Teknologi Pengolahan Makanan Ringan (Vacuum Frying, Deep Frying dan Spinner) untuk Meningkatkan Kualitas
Makanan Olahan di Banjarnegara. Laporan Hasil Litbang Balai Besar Pengembangan Mekanisasi Pertanian Badan Penelitian dan Pengembangan Kementrian Pertanian. Banten. 